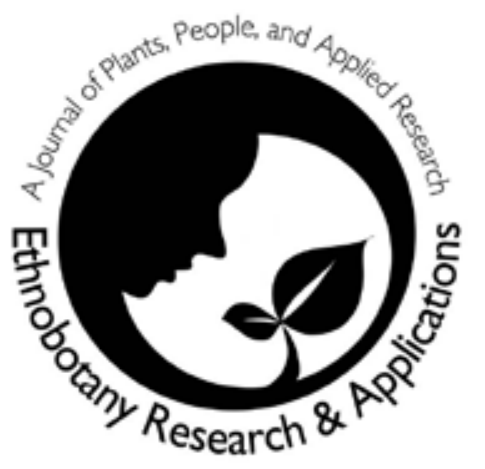

\title{
The Biodiversity of Your Refrigerator: An Exercise in Food Origins
}

\author{
Nat Bletter
}

\section{Education}

\begin{abstract}
Students often have little idea of where the food they eat every day originates and which of their staple foods come from their ancestral homelands. By doing a quick, simple inventory of the origins of the foods and ingredients in their refrigerators, students can become much more aware of whether they are eating predominantly their native foods or the foods of their adopted country. This exercise ties into a series of pertinent topics of current concern: the global food supply, the distance food must travel from farm to table, nutrition, and changes of diets through history. The exercise was assigned to a class of nineteen students from ten countries (China, Cuba, Dominican Republic, Ecuador, Jamaica, Nigeria, Peru, Philippines, Puerto Rico, and United States) to fully test it. Although not statistically significant with this small sample size, one interesting yet non-significant trent that emerged was that students who had been in the U.S. longer were using fewer foods from their ancestral area and more foods from their adopted area (Northeastern U.S.), while increasing their food family diversity.
\end{abstract}

\section{Background}

Market surveys have been common and powerful tools for ethnobotanists to determine the diversity, commonalities, and differences between ethnic and mainstream markets (Bye \& Linares 1983, Mertz et al. 2001, Williams et al. 2000), especially for the analysis of immigrant populations' food choices and diversity (Nguyen 2005). Surveys of home gardens (Coomes \& Ban 2004, Hamlin \& Salick 2003) have been another useful tool to analyze household food diversity and consumption, but in modern cities where people do not grow their own fruit and vegetables due to lack of space, cost, time, or the wrong climate, we can instead look to people's refrigerators to get a good idea of their changing patterns of food use and diversity. Nguyen (2003) has explained how the diversity of US im- migrants' diets have increased at least in the case of Vietnamese immigrants to Hawai'i. In addition to aiding crop resilience (FAO 1997), this diversity of foods has shown to be essential to better nutrition and health (FAO 1997, McDade et al. 2007). Therefore, students understanding of their diets' origins, diversity, and production is essential to their cultural identity and health.

As part of a master's-level economic botany class taught at Lehman College of the City University of New York that was composed mostly of high school science teachers, each student was asked to create a table with a row for each basic food or ingredient in his or her refrigerator. This was limited to plant foods (no fungi, meat, dairy, or fish) and was capped at 40 items, as to not penalize students with a more diverse diet with extra effort. For each item, they were asked to list the common name; species; family; center of origin of the species from Vavilov's list of eight centers of origin for cultivated plants: China, Central Asia, Middle/Near East, Indo-Malaya, Mediterranean, Abyssinia, Mexico-Central America, and South America (Vavilov 1951); whether the plant is of North American origin (Vavilov's Mexico/Central American center), i.e. native

\section{Correspondence}

Nat Bletter, City University of New York Graduate Center/New York Botanical Garden

New York, New York, U.S.A.

nbletter@yahoo.com

Ethnobotany Research \& Applications 5:233-240 (2007) 
Table 1. A sample list of food items found in the refrigerator of a student with Ukrainian ancestors, including the species name, family, center of origin, North American origin, and ancestral origin of each item.

\begin{tabular}{|c|c|c|c|c|}
\hline $\begin{array}{l}\text { Vavilov's } \\
\text { Origin }\end{array}$ & $\begin{array}{l}\text { Common } \\
\text { Name }\end{array}$ & Species, Family & $\begin{array}{l}\text { North } \\
\text { American }\end{array}$ & Ancestral \\
\hline \multicolumn{3}{|l|}{ Abyssinia } & No & No \\
\hline & Aloe vera & \multicolumn{3}{|l|}{ Aloe vera (L.) Burm.f., Asphodelaceae } \\
\hline & Argan & \multicolumn{3}{|l|}{ Argania spinosa (L.) Skeels, Sapotaceae } \\
\hline & Basil & \multicolumn{3}{|l|}{ Ocimum basilicum L., Lamiaceae } \\
\hline & Sesame & \multicolumn{3}{|l|}{ Sesamum orientale L., Pedaliaceae } \\
\hline \multicolumn{3}{|c|}{ Central America } & Yes & No \\
\hline & Maple syrup & \multicolumn{3}{|l|}{ Acer saccharum Marshall, Sapindaceae } \\
\hline & Agave nectar & \multicolumn{3}{|l|}{ Agave americana L., Agavaceae } \\
\hline & Chili & \multicolumn{3}{|l|}{ Capsicum annuum L., Solanaceae } \\
\hline & Oregon grape & \multicolumn{3}{|l|}{ Mahonia aquifolium (Pursh) Nutt., Berberidaceae } \\
\hline & Avocado & \multicolumn{3}{|l|}{ Persea americana Miller, Lauraceae } \\
\hline & Beans & \multicolumn{3}{|l|}{ Phaseolus vulgaris L., Fabaceae } \\
\hline & Sumac & \multicolumn{3}{|l|}{ Rhus hirta (L.) Sudw., Anacardiaceae } \\
\hline & Elderberry & \multicolumn{3}{|l|}{ Sambucus canadensis L., Caprifoliaceae } \\
\hline \multicolumn{3}{|c|}{ Central Andean } & No & No \\
\hline & Peanut & \multicolumn{3}{|l|}{ Arachis hypogaea L., Fabaceae } \\
\hline & Tomato & \multicolumn{3}{|l|}{ Lycopersicon esculentum Miller, Solanaceae } \\
\hline & Chocolate & \multicolumn{3}{|l|}{ Theobroma cacao L., Malvaceae } \\
\hline \multicolumn{3}{|c|}{ Central Asia } & No & Yes \\
\hline & Onion & \multicolumn{3}{|l|}{ Allium cepa L., Liliaceae } \\
\hline & Tat soi & \multicolumn{3}{|l|}{ Brassica rapa L., Brassicaceae } \\
\hline & Walnut & \multicolumn{3}{|l|}{ Juglans regia L., Juglandaceae } \\
\hline & Apple & \multicolumn{3}{|l|}{ Malus domestica Borkh., Rosaceae } \\
\hline & Almond & \multicolumn{3}{|l|}{ Prunus dulcis (Miller) D. Webb, Rosaceae } \\
\hline & Rose hips & \multicolumn{3}{|l|}{ Rosa canina L., Rosaceae } \\
\hline \multicolumn{3}{|l|}{ China } & No & No \\
\hline & Tea & Camellia sinensis (L.) Kuntze, Theaceae & & \\
\hline & Lime & Citrus aurantifolia (Christm.) Swingle, Rutaceae & & \\
\hline & Soy & Glycine max (L.) Merr., Fabaceae & & \\
\hline Indo-Mala & & & No & No \\
\hline & Candle nut & Aleurites moluccana (L.) Willd., Euphorbiaceae & & \\
\hline & Cinnamon & Cinnamomum verum J. Presl., Lauraceae & & \\
\hline & Coconut & Cocos nucifera L., Arecaceae & & \\
\hline & Hibiscus & Hibiscus sabdariffa L., Malvaceae & & \\
\hline & Banana & Musa acuminata $X$ balbisiana Colla, Musaceae & & \\
\hline & Pandanus & Pandanus amaryllifolius Roxb., Pandanaceae & & \\
\hline & Ginger & Zingiber officinale Roscoe, Zingiberaceae & & \\
\hline Mediterran & ean & & No & No \\
\hline & Hazelnuts & Corylus avellana L., Betulaceae & & \\
\hline & Artichokes & Cynara scolymus L., Asteraceae & & \\
\hline & Carrots & Daucus carota L., Apiaceae & & \\
\hline
\end{tabular}




\begin{tabular}{|l|l|l|l|l|}
\hline $\begin{array}{l}\text { Vavilov's } \\
\text { Origin }\end{array}$ & $\begin{array}{l}\text { Common } \\
\text { Name }\end{array}$ & Species, Family & $\begin{array}{l}\text { North } \\
\text { American }\end{array}$ & Ancestral \\
\hline \multirow{5}{*}{ Near East } & Lettuce & Lactuca sativa L., Asteraceae & \multicolumn{3}{l|}{} \\
\cline { 2 - 5 } & Olive & Olea europaea L., Oleaceae & No & No \\
\hline \multirow{5}{*}{} & Flax (oil) & Linum usitatissimum L., Linaceae & \multicolumn{3}{l|}{} \\
\cline { 2 - 6 } & Radish & Raphanus sativus L., Brassicaceae & $\mathbf{2 0 \%}$ & $\mathbf{1 5 \%}$ \\
\cline { 2 - 6 } & Wheat & Triticum aestivum L., Poaceae & $\mathbf{2 0}$ \\
\cline { 2 - 6 } & Grapes & Vitis vinifera L., Vitaceae & \multicolumn{3}{|l}{} \\
\hline $\mathbf{9}$ & $\mathbf{4 0}$ & $\mathbf{4 0 , 3 2}$ &
\end{tabular}

to the area where the students were currently living; and whether the plant's center of origin is the same as the students' ancestral geographic area (Table 1). Students were referred to the books Economic Botany (Simpson \& Conner-Ogorzaly 2001), The Origin, Variation, Immunity and Breeding of Cultivated Plants (Vavilov 1951), and Cornucopia II (Facciola 1998) and the Internet, including Gernot Katzer's Spice pages (www.uni-graz.at/ katzer/engl/) to determine species, family, and origin of each food. Vavilov did not provide a very clear map of the extent of his eight centers of domestication and some key areas are omitted (e.g., temperate North America). These and trying to distinguish between the origin of a species and the location of first domestication may confuse some students, so other authors such as Harlan (1992) can be referenced for centers of origin. For high school teachers without access to a large botanical library, the high school-oriented text book by Paye (2000) is a good basic reference on the field of ethnobotany and food.
In addition, the students were asked to record what they consider their ancestral area, how many years they have been in the Northeastern United States where the class was conducted, how many years it took them to find the current set of businesses from which they purchase their food, and to calculate the total number of species, families, and centers of origin, the percentage of North American and ancestral foods, and the reciprocal Simpson's diversity index for the number of plant families and center of origins they found in their refrigerator as

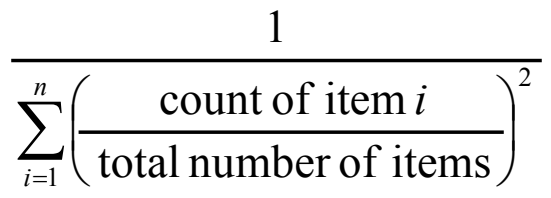

(see Tables 2 and 3). The Simpson's diversity index is used as another way to measure diversity aside from a simple family count, and to help educate students about

Table 2. Reciprocal Simpson's diversity index calculation for families of the sample refrigerator plant food items.

\begin{tabular}{|l|c|l|}
\hline Family & Count & (frequency/total items) \\
\hline Agavaceae & 1 & 0.000625 \\
\hline Asphodelaceae & 1 & 0.000625 \\
\hline Anacardiaceae & 1 & 0.000625 \\
\hline Apiaceae & 1 & 0.000625 \\
\hline Arecaceae & 1 & 0.000625 \\
\hline Asteraceae & 2 & 0.0025 \\
\hline Berberidaceae & 1 & 0.000625 \\
\hline Betulaceae & 1 & 0.000625 \\
\hline Brassicaceae & 2 & 0.0025 \\
\hline Theaceae & 1 & 0.000625 \\
\hline Caprifoliaceae & 1 & 0.000625 \\
\hline Euphorbiaceae & 1 & 0.000625 \\
\hline Fabaceae & 3 & 0.005625 \\
\hline Juglandaceae & 1 & 0.000625 \\
\hline Lamiaceae & 1 & 0.000625 \\
\hline Lauraceae & 2 & 0.0025 \\
\hline Liliaceae & 1 & 0.000625 \\
\hline
\end{tabular}

\begin{tabular}{|l|c|l|}
\hline Family & Count & (frequency/total items) $^{\mathbf{2}}$ \\
\hline Linaceae & 1 & 0.000625 \\
\hline Malvaceae & 2 & 0.0025 \\
\hline Musaceae & 1 & 0.000625 \\
\hline Oleaceae & 1 & 0.000625 \\
\hline Pandanaceae & 1 & 0.000625 \\
\hline Pedaliaceae & 1 & 0.000625 \\
\hline Poaceae & 1 & 0.000625 \\
\hline Rosaceae & 3 & 0.005625 \\
\hline Rutaceae & 1 & 0.000625 \\
\hline Sapindaceae & 1 & 0.000625 \\
\hline Sapotaceae & 1 & 0.000625 \\
\hline Solanaceae & 2 & 0.0025 \\
\hline Vitaceae & 1 & 0.000625 \\
\hline Zingiberaceae & 1 & 0.000625 \\
\hline Total: 32 & $\mathbf{4 0}$ & $\mathbf{0 . 0 3 8 7 5}$ \\
\hline Simpson's Reciprocal Diversity Index: 25.8 \\
\hline
\end{tabular}




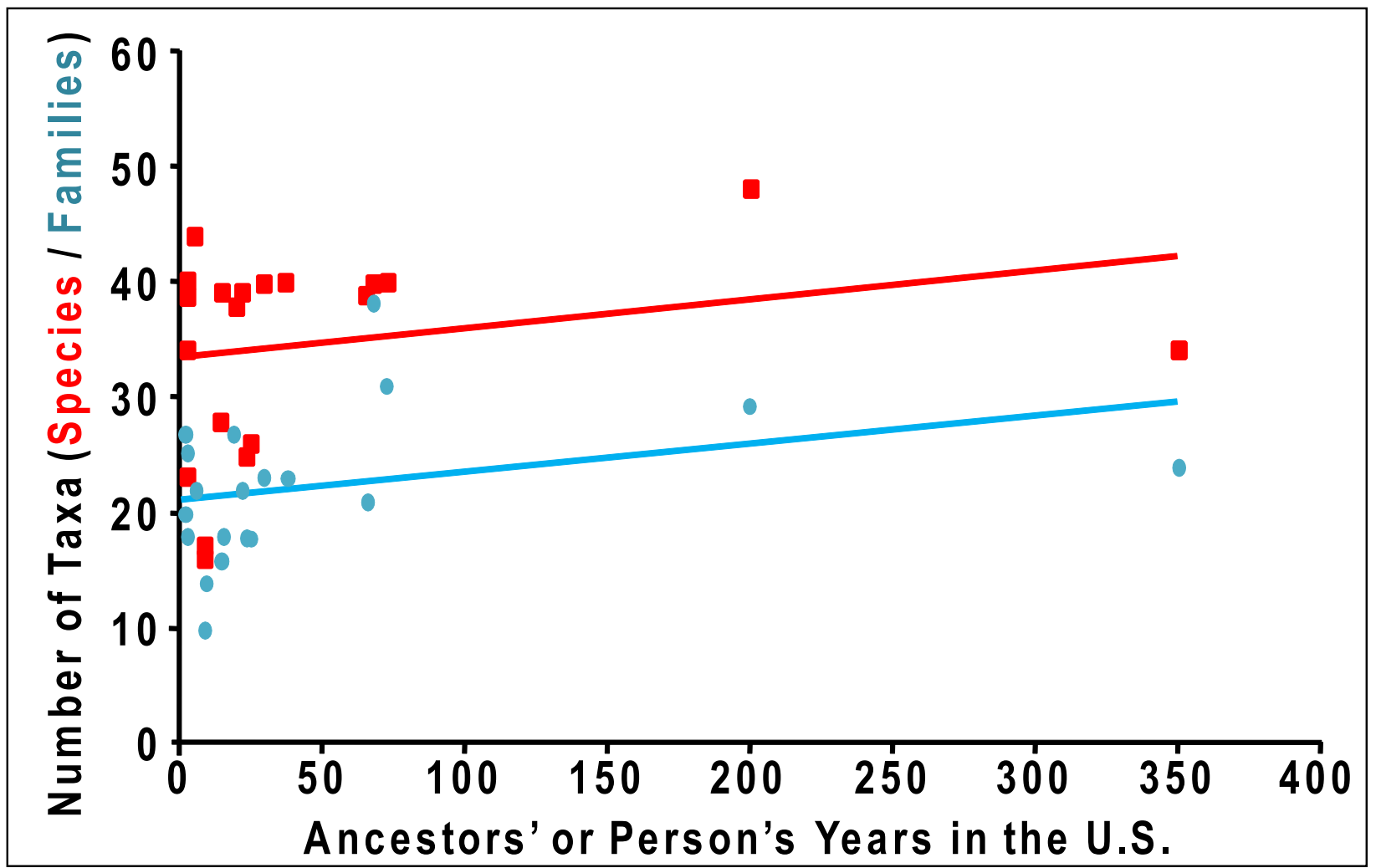

Figure 1. Species (red squares) and family (blue ovals) counts of refrigerator plant food items vs. years spent in the country with linear regressions for each. For the species count regression, $R^{2}=0.0588$ and $p=0.303$ and for the family count regression, $R^{2}=0.1016$ and $p=0.189$. No significant trend.

ecological diversity indices (Magurran 1988, Pielou 1977). For teachers without access to these books or those looking for a simple explanation of these indices, there are several excellent websites describing this calculation and ecological statistics in general: http://tiee.ecoed.net/vol/ v5/practice/dalgleish/faculty.html (includes very complete spreadsheet data and calculation downloads), www.coun-

Table 3. Reciprocal Simpson's diversity index calculation for centers of origin of the sample refrigerator plant food items.

\begin{tabular}{|l|c|l|}
\hline Center of Origin & Count & (frequency/total items) $^{\mathbf{2}}$ \\
\hline Abyssinia & 4 & 0.01 \\
\hline Central America & 8 & 0.04 \\
\hline Central Andean & 3 & 0.005625 \\
\hline Central Asia & 6 & 0.0225 \\
\hline China & 3 & 0.005625 \\
\hline Indo-Malaya & 7 & 0.030625 \\
\hline Mediterranean & 6 & 0.0225 \\
\hline Near East & 3 & 0.005625 \\
\hline Total: 8 & $\mathbf{4 0}$ & $\mathbf{0 . 1 4 2 5}$ \\
\hline Simpson's Reciprocal Diversity Index: $\mathbf{7 . 0 1 7 5 4 3 8 6}$ \\
\hline
\end{tabular}

trysideinfo.co.uk/simpsons.htm, http://botanika.bf.jcu. cz/suspa/FunctDiv.php (includes a spreadsheet download, though lacking the reciprocal Simpson's index), and www.tiem.utk.edu/ mbeals/simpsonDI.html.

If there was some uncertainty of the exact species of a food plant due to several species having the same common name, such as mint (Mentha piperata or M. spicata), the students were required only to ascertain the correct genus, and not the species.

\section{Results}

When the number of species, families, and centers of origins and percentage of North American and ancestral foods are plotted for the entire class versus the number of years the students or their ancestors have been in the local area, some interesting patterns emerged. The working hypothesis was that the percentage of ancestral foods correlates negatively with the number of years in the U.S., i.e. the longer people were in the U.S., the fewer foods they would eat from their ancestral area, as they adopted the local food and forgot or lost the use of their ancestral foods. Nabhan (2002) among others has commented on how immigrants lose the use of the food from their homeland, at least over several generations, if 


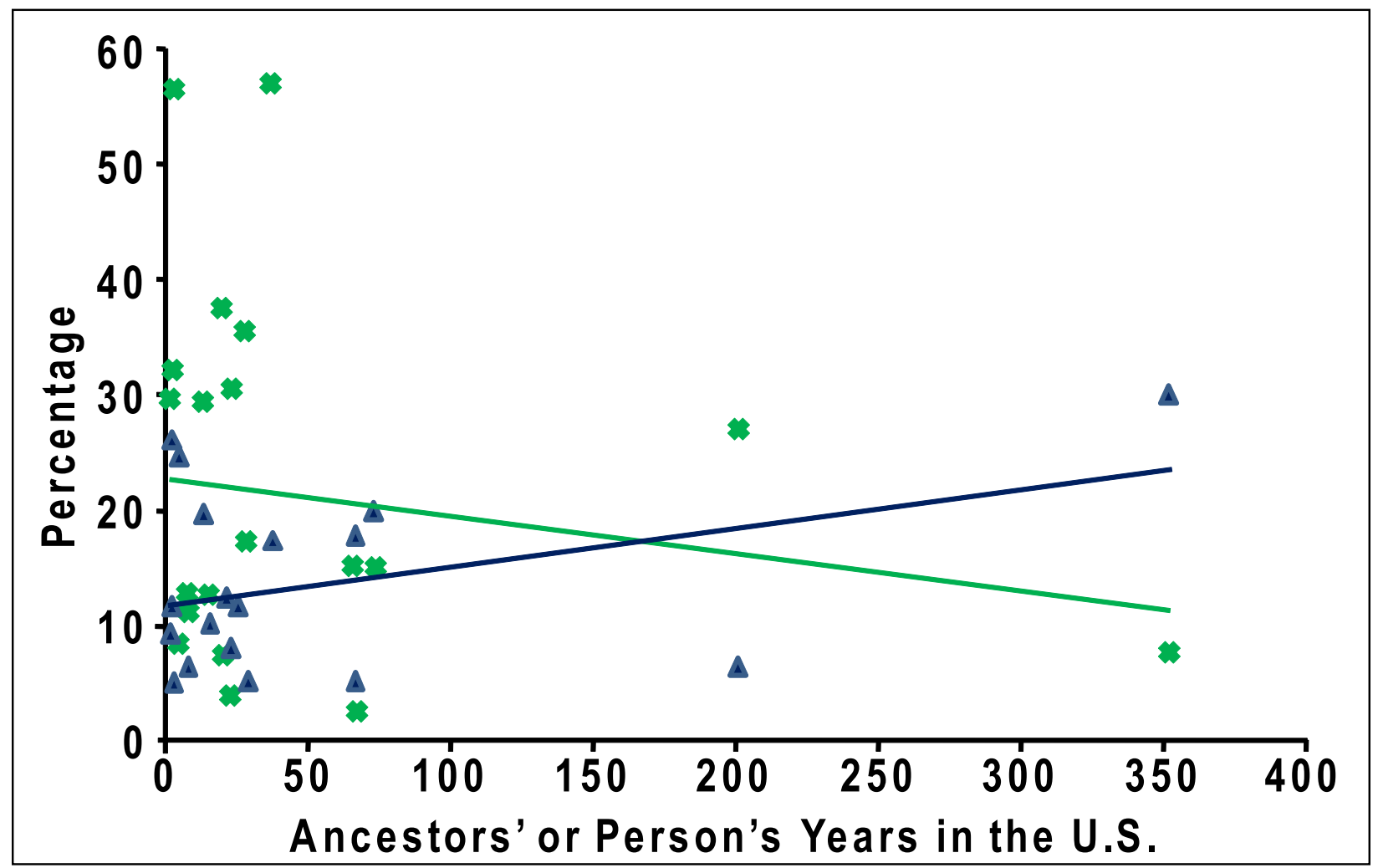

Figure 2. Percent of ancestral (green x's) and North American (purple triangles) refrigerator food items vs. years spent in the country with linear regressions. For the ancestral percentage regression, $R^{2}=0.0275$ and $p=0.489$ and for the North American percentage regression, $R^{2}=0.128$ and $p=0.121$. No significant trend.

not within one generation. Several researchers have commented on the connections of diet biodiversity and health (FAO 1997, McDade et al. 2007), and having students understand the diversity and sources of their diet could potentially have some beneficial impact on their diet choices in the current atmosphere of narrowing monocrop agriculture, obesity and diabetes epidemics.

When the data were analyzed for the nineteen people in our economic botany class from ten countries (Jamaica, United States, Nigeria, Philippines, China, Puerto Rico, Dominican Republic, Ecuador, Peru, and Cuba; see Figures 1, 2, and 3) the largest trends, although not statistically significant due to the small sample size, was indeed that the longer someone had been in the Northeastern U.S., the lower the percentage of foods they were $\left(R^{2}=0.128\right.$, $p=0.121)$. The species count statistics $\left(R^{2}=0.0588, p=\right.$ 0.303 ) are difficult to trust as the students were asked to limit their species to 40 . The family count trend was interesting with a relatively high correlation $\left(R^{2}=0.1016, p=\right.$ 0.189 ), possibly due to the fact that there is a very large food family diversity available in the US, especially in culturally diverse New York City with its many imported food stores. Students may become more exposed to this diversity the longer they are in the area, trying foods from other cultures. For examples, in one informal survey, food items in 86 plant families were found in markets within a few mile radius of our school in the Bronx (Raz, L. \& A. Roberts, personal communication, 2004).

\section{Possible Variations and Future Work}

There are many possible variations and extensions to this basic assignment when it is aimed at different grade levels. The question about North American origin can be changed to wherever the students are currently living, to determine what percentage of foods the students are eating from their adopted country. Students can be asked to compute diversity indices such as those of Simpson, Shannon, or Margalef on a selection of all of the species, family, or center of origin data they have collected (Magurran 1988, Pielou 1977). Calculating these diversity indices that are used regularly in ecology helps students understand these complicated measures in a way that is very personal and gives the students other means of measuring the biodiversity of their food. They can be asked to determine if the percentage of North American or ancestral foods is significant using the chi-square test (Sokal \& Rohlf 1994) a non-parametric test that is used to test for a significant difference of non-continuous tabular data on two groups. 


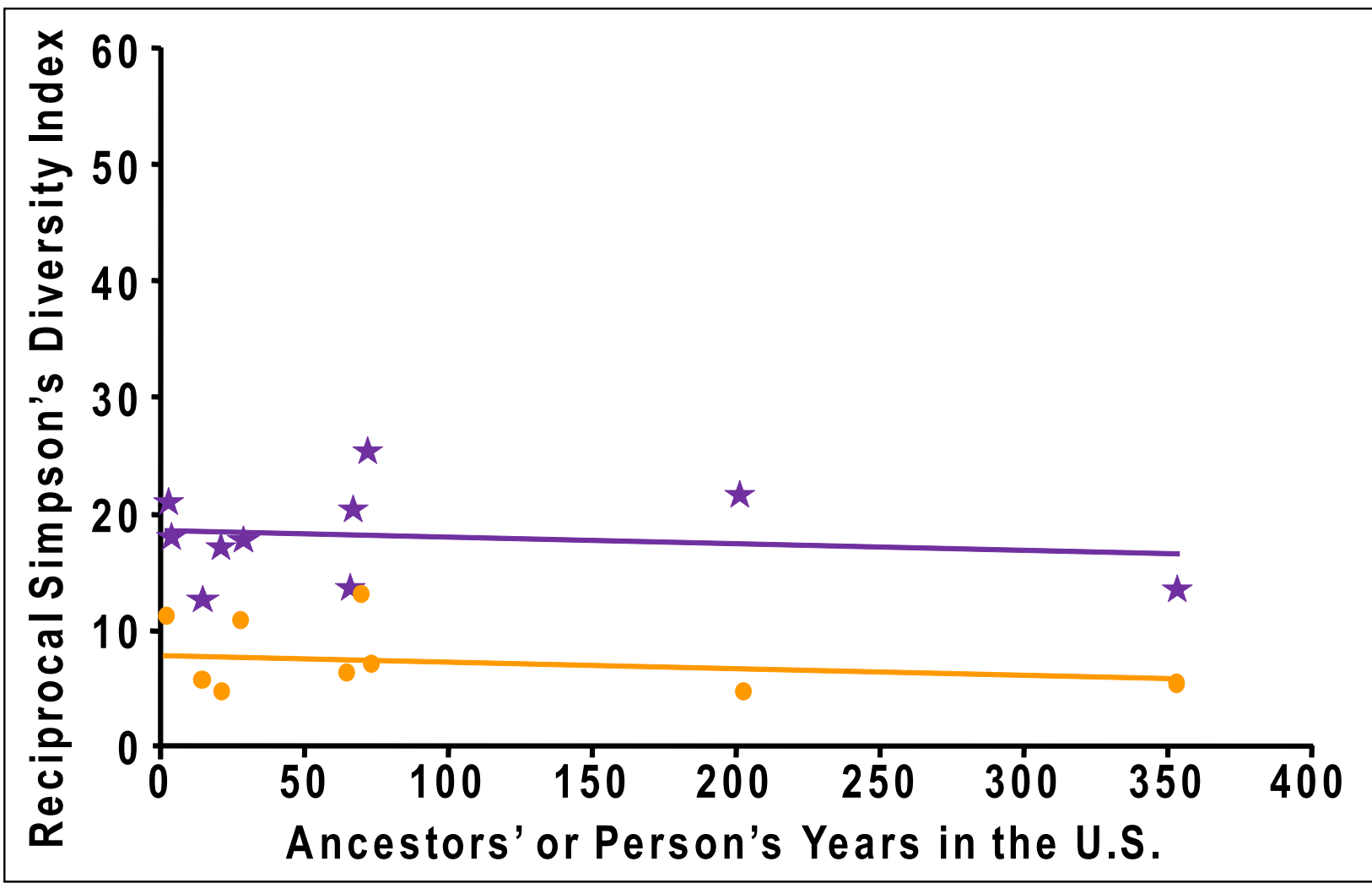

Figure 3. Reciprocal Simpson's diversity index for number of plant families (purple stars) and center of origin (orange circles) of refrigerator plant food items vs. years spent in the country with linear regressions. For the for the family diversity regression, $R^{2}=0.0239$ and $p=0.652$ and for the center of origin diversity regression, $R^{2}=0.0171$, and $p=$ 0.737 . No significant trend.

To find whether the cause of the change in ancestral foods over time is related to finding local stores, the students can be asked how many local stores they go to, the distance to each store, and the type of each store. If students have been in the local area since they were born, they can be asked for how many years or generations their ancestors have lived in the local area.

Students can be asked to see how any of the measures of biodiversity varies with the age or gender of their classmates, and to extend these measures to their family members if the contents of the family members' refrigerators can be easily determined. How intra-family factors affect refrigerator food diversity can be measured, recorded, and added to the analysis. For instance, student can record whether they helped with shopping, if they lived with several generations in the same household, and if they made regular visits to their birthplace where they may have picked up additional local foods and uses. If possible, interview techniques may be taught from sources such as Alexiades (1996) and Martin (1995) to ask available family members and older generation immigrants what foods they had in their refrigerators or pantries, extending the study back in time.
To examine whether students are eating locally grown foods rather than the historical local crop origins of the food, students can be asked to determine where each of the species in their refrigerators was grown. This may entail much more work, especially with prepared foods, where a call to a company would be necessary to find out each ingredient's origin. Even with fresh produce in a supermarket, it may be difficult to find someone in the store who knows where each item originates, but this kind of research will go a long way towards illustrating to the students how far their food must travel from where it is grown to their table, often cited as averaging 1500 miles in the U.S. (Nabhan 2002). Decreasing the food miles of one's diet may at first seem in opposition to the goals of increasing the diet's biodiversity as one may be limited to certain local store-bought foods, but both these goals can be met by learning about the wealth of local traditional and wild foods, gaining an even better understanding of ethnobotany and the origins of agriculture.

Variations in use of native vs. non-native foods with immigrants from different areas of the world would be an additional interesting question to analyze in future incarnations of this study. I would hypothesize that immigrants from high food-crop diversity areas (e.g. Vavilov's centers of domestication) would use a much higher percentage 


\section{Bletter - The Biodiversity of Your Refrigerator: An Exercise in Food Origins 239}

of foods from their native area than those from low foodcrop diversity areas, even many years after immigrating. For examples, from my personal observation (2003 and 2004), the majority of food plants sold in markets in Mali were introduced species (e.g., Amaranthus sp., Anacardium occidentale L., Arachis hypogaea L., Lycopersicon esculentum Miller, Mangifera indica L., Musa acuminata $X$ balbisiana Colla, Oryza sativa L., Phaseolus vulgaris L., Solanum melongena L., Solanum tuberosum L., and Triticum aestivum L.) with few of the native foods (e.g., millet, Pennisetum glaucum L. and sorghum, Sorghum bicolor (L.) Moench) in evidence, whereas the majority of food plants sold in markets in Peru were native (e.g., Amaranthus sp. A. occidentale, Ananas comosus (L.) Merr., Capsicum pubescens Ruiz \& Pav., Chenopodium quinoa Willd., L. esculentum, Persea americana Mill., Phaseolus vulgaris L., Phaseolus lunatus L., Physalis peruviana L., Psidium guajava L., S. tuberosum) with only a few introduced species ( $M$. indica, Musa acuminata $X$ balbisiana Colla, O. sativa, T. aestivum) which may be due to the fact that Peru is a center of many food crop origins and domestication while Mali is not. Determining the subtle differences between different areas of the world will clearly require a much higher sample size to attain significance, but these are all questions we plan to ask when this class assignment is conducted in the future, which we hope will lead to statistically significant results. We feel that this exercise is useful to educators of many different levels for teaching about biodiversity and its measures, statistics in general, ethnobotany, plant relations, binomial nomenclature, food origins, and immigrant diets.

\section{Conclusion}

The exercise described here may be given to students of any age by varying the complexity of questions and provides a hands-on, personal way for each student to learn about the origins of the foods they eat every day. This helps students reconnect with where their food is grown, how far it has traveled to reach their table, and whether it is part of their cultural heritage. For students to understand how traditional farming and food distribution are changing worldwide, this is essential information. The overriding goal is to increase awareness of the diverse provenances and origins of the plant foods people eat every day, and how plant foods comprise an important part of one's cultural heritage. Verification of the hypothesis that students will eat fewer ancestral foods the longer they are away from their birth country will have to wait for a larger sample size, but this exercise will help them answer that question for themselves and their classmates while learning about crop origins and useful biodiversity measures.

\section{Acknowledgements}

I would like to thank all my students from the Economic Botany class (Geneve Hall, Isabel Murray, Lourdes Ro- sario, Novelett Foote, Pamela Meyer, Peta-rose Blake, Rasheen Allen, Rowena Garana, Uchenna Unachukwu, Ziping Liu, Christina Arce, Maria Day, Roberta Hrdy, Elsa Meza, William Perez, Krystle Smith, Ruth Taveras, Joanna Condo, Eva Burgos) who searched through their refrigerators to collect these data and showed such interest in their food's provenance; I also thank Dwight Kincaid and Doug Daly for advice and assistance.

\section{Literature Cited}

Alexiades, M.N. 1996. Selected Guidelines for Ethnobotanical Research: A field manual. New York Botanical Garden, Bronx, New York.

Bye, R.A. \& E. Linares. 1983. The role of plants found in Mexican markets and their importance in ethnobotanical studies. Journal of Ethnobiology 3:1-13.

Coomes, O.T. \& N. Ban. 2004. Cultivated Plant Species Diversity in Home Gardens of an Amazonian Peasant Village, Northeastern Peru. Economic Botany 58:420-434.

Facciola, S. 1998. Cornucopia II: A source book of edible plants. Kampong Publications, Vista, CA.

FAO. 1997. Agriculture Food and Nutrition for Africa - A resource book for teachers of agriculture. Food and Nutrition Division, Publishing Management Group, FAO Information Division, Rome.

Hamlin, C. \& J. Salick. 2003. Yanesha Agriculture in the Upper Peruvian Amazon: Persistence and Change Fifteen Years Down the 'Road.' Economic Botany 57:163-180.

Harlan, J.R. 1992. Crops and Man. American Society of Agronomy, Madison, WI.

Magurran, A.E. 1988. Ecolological Diversity and its Measurement. Princeton University Press, Princeton, NJ.

Martin, G.J. 1995. Ethnobotany: A methods manual. Chapman \& Hall, London.

McDade, T.W., V. Reyes-Garcia, P. Blackinton, S. Tanner, AT. Huanca \& W.R. Leonard. 2007. Ethnobotanical Knowledge is Associated with Indices of Child Health in the Bolivian Amazon. Proceedings of the National Academy of Sciences of the United States of America 104: 6134-6139.

Mertz, O., A.M. Lykke, A. Reenberg. 2001. Importance and Seasonality of Vegetable Consumption and Marketing in Burkina Faso. Economic Botany 55:276-289.

Nabhan, G.P. 2002. Coming Home to Eat: The pleasures and politics of local foods. W.W. Norton \& Company, New 
York.

Nguyen, M.T. 2003. Comparison of Food Plant Knowledge between Urban Vietnamese Living in Vietnam and in Hawai'i. Economic Botany 57:472-480.

Nguyen, M.T. 2005. Cultivated Plant Collections from Market Places. Ethnobotany Research and Applications 3:5-15.

Paye, G.D. 2000. Cultural Uses of Plants: A guide to learning about ethnobotany. New York Botanical Garden Press, Bronx, New York.

Pielou, E.C. 1977. Mathematical Ecology. Wiley, New York.

Simpson, B.B. \& M. Conner-Ogorzaly 2001. Economic Botany: Plants in our world. McGraw-Hill, Boston.

Sokal, R.R. \& F.J. Rohlf 1994. Biometry: The principles and practice of statistics in biological research. W.H. Freeman \& Company, New York.

Vavilov, N.I. 1951. The Origin, Variation, Immunity and Breeding of Cultivated Plants: Selected writings of N.I. Vavilov. Chronica Botanica Company, Waltham, Mass.

Williams, V.L., K. Balkwill \& E.T.F. Witkowski. 2000. Unraveling the Commercial Market for Medicinal Plants and Plant Parts on the Witwatersrand South Africa. Economic Botany 54:310-327. 